ПЕДАГОГІЧНІ УМОВИ ПРОФЕСІЙНОГО РОЗВИТКУ ВЧИТЕЛІВ ПОЧАТКОВОЇ ШКОЛИ В СИСТЕМІ МЕТОДИЧНОЇ РОБОТИ ЗАКЛАДІВ ЗАГАЛЬНОЇ СЕРЕДНЬОЇ ОСВІТИ

\title{
PEDAGOGICAL CONDITIONS OF PROFESSIONAL DEVELOPMENT OF PRIMARY SCHOOL TEACHERS IN THE SYSTEM OF METHODOLOGICAL WORK OF GENERAL SECONDARY EDUCATION INSTITUTIONS
}

Стаття присвячена актуальній проблемі профресійного розвитку вчителів початкової школи в системі методичної роботи закладів загальної середньої освіти. Здійснений огляд наукових джерел щодо визначення педагогічних умов профресійного розвитку вчителів початкової школи в системі післядипломної освіти. Основна увага зосереджується на визначенні термінів «умови», «педагогічні умови»; обгрунтовано такі педагогічні умови, які сприяють професійному розвитку вчителів початкової школи в системі методично роботи закладів загальної середньої освіти. Визначено, що педагогічні умови розуміють як певні обставини, які сприяють (або протидіють) проявам педагогічних закономірностей, обумовлених дією фракторів, або обумовлюють певний напрям розвитку педагогічного процесу. На основі аналітичного огляду психолого-педагогічної літератури педагогічні умови профресійного розвитку вчителів початкової школи в системі методичної роботи закладів загальної середньої освіти розуміємо як сукупність обставин, які забезпечують ефективність прочесу професійного розвитку вчителя початкової школи в системі методичної роботи закладів загальної середньої освіти. Виокремлено такий спектр педагогічних умов: створення інноваційного професійного електронного середовища в системі методичної роботи; оновлення змісту діяльності методичного об'єднання учителів початкової школи, орієнтованого на вдосконалення профресійного розвитку вчителів початкової школи; залучення вчителів початкової школи до різних інноваційних форм методичної роботи; системна взаємодія методичних установ (школи, району, об'єднаної територіальної громади); відкритість і співпраця, що забезпечуються залученням батьків (особами, які їх замінюють), представників громадських організацій, наукових і методичних установ, засобів масової інформації. Передбачається, що соормування окреслених педагогічних умов сприятиме ефективності технологіі професійного розвитку вчителів початково ̈ иколи в системі методичної роботи закладів загальної середньої освіти.

Ключові слова: професіійний розвиток учителів початкової школи, система методичної роботи, педагогічні умови, педагогічні умови профресійного розвитку вчителів початкової школи в системі методичної роботи закладів загальної середньо освіти, Нова українська школа.
The article is devoted to the topical problem of professional development of primary school teachers in the system of methodical work of general secondary education institutions. A review of scientific sources to determine the pedagogical conditions for professional development of primary school teachers in the system of postgraduate education. The main attention is focused on the defined terms "conditions", "pedagogical conditions", defined and justified such pedagogical conditions that contribute to the professional development of primary school teachers in the system of methodical work of general secondary education institutions. It is determined that pedagogical conditions are understood as certain circumstances that contribute (or counteract) the manifestations of pedagogical patterns due to the action of factors or determine a certain direction of development of the pedagogical process. Based on the analytical review of psychological and pedagogical literature, pedagogical conditions of professional development of primary school teachers in the system of methodical work of secondary schools are understood as a set of circumstances that ensure the effectiveness of the process of professional development of primary school teachers in the system of methodical work of secondary schools. The following spectrum of pedagogical conditions is distinguished: creation of innovative professional electronic environment in the system of methodical work; updating the content of the activities of the methodological association of primary school teachers focused on improving the professional development of primary school teachers; involvement of primary school teachers in various innovative forms of methodical work; system interaction of methodical institutions (school, district, UTC); openness and cooperation provided by the involvement of parents (persons who replace them), representatives of public organizations, scientific and methodological institutions, the media. It is assumed that the formation of the outlined pedagogical conditions will contribute to the effectiveness of the technology of professional development of primary school teachers in the system of methodical work of general secondary education institutions.

Key words: professional development of primary school teachers, system of methodological work, pedagogical conditions, pedagogical conditions of professional development of primary school teachers in the system of methodical work of general secondary education institutions, New Ukrainian school. наук України

Постановка проблеми в загальному вигляді. Українська освіта переходить на новий щабель розвитку та $є$ атрибутом сучасної розвиненої країни. Розвиток освітньої галузі має стати пріоритетом держави. Визначальною особливістю змін, які відбуваються в освіті України, є перехід до навчання за концепцією Нової української школи (далі НУШ), спрямованого на фрормування в учнів здатностей творчо діяти, отримувати знання й застосовувати їх на практиці. Відповідно до цієї концепції зміна мети системи освіти вказує на потребу корегування методик і технологій навчання, його змісту 
зі спрямуванням на формування світогляду й особистих ціннісних орієнтацій, навчання самостійної підготовки, самонавчання, розвитку здатностей до самопізнання й самореалізації, вміння критично мислити, користуватися засобами інорормаційних технологій. У цьому контексті актуальності набуває проблема професійного розвитку вчителів початкової школи в системі методичної роботи закладів загальної середньої освіти. Відповідно виникає необхідність виокремлення й обґрунтування педагогічних умов професійного розвитку вчителів початкової школи в системі методичної роботи закладів загальної середньої освіти, що сприятимуть їхньому професійному розвитку й підвищенню соціального статусу в цілому.

Аналіз останніх досліджень і публікацій. У контексті нашого дослідження було виявлено, що проблемі профресійного розвитку педагогів і визначенню педагогічних умов професійного розвитку в системі післядипломної освіти приділяли увагу такі науковці, як Ю. Бабанський, М. Бирка, Н. Бібік, Ю. Завалевський, І. Зязюн, Л. Карташова, Н. Клокар, О. Корнєєва, В. Кремень, Н. Кузьміна, В. Олійник, О. Пєхота, І. Підласий, Л. Пуховська, О. Савченко, В. Сластьонін, Т. Сорочан, Л. Хоружа, Є. Хриков, А. Хуторський та інші.

Виділення не вирішених раніше частин загальної проблеми. Однак проведений аналіз наукових праць і практики досліджуваної проблеми дає змогу констатувати, що проблема професійного розвитку педагогічних працівників в системі післядипломної освіти в нових умовах потребує подальшого дослідження й уточнення.

Мета статті. Визначити й обґрунтувати педагогічні умови професійного розвитку вчителів початкової школи в системі методичної роботи закладів загальної середньої освіти.

Виклад основного матеріалу. Важливим для розроблення технології професійного розвитку вчителів початкової школи в системі методичної роботи закладів загальної середньої освіти є виокремлення педагогічних умов.

Слід зазначити, що в Академічному тлумачному словнику поняття «умова» тлумачиться як «взаємна усна чи письмова домовленість про що-небудь; угода, договір» [2]. Психологи визначають умову як сукупність явищ довкілля та внутрішнього середовища, що ймовірно впливає на розвиток конкретного психічного явища [4, с. 243]. Отже, можна дійти висновку, що умови - це певні обставини, які безпосередньо впливають на розвиток суб'єкта чи об'єкта.

3 метою окреслення педагогічних умов професійного розвитку вчителів початкової школи в системі методичної роботи закладів загальної середньої освіти ми звернулися до наукових педагогічних джерел. 3'ясовано, що поняття «педагогічні умови» розглядали такі науковці, як Ю. Бабан- ський [3], І. Зязюн [5], Н. Кузьміна [7], О. Пєхота [9], І. Підласий[11], В. Сластьонін [14], Є. Хриков [15], А. Хуторський [16] та інші.

Так, на думку Ю. Бабанського, педагогічні умови - це відповідні фрактору педагогічні обставини, які сприяють (або протидіють) проявам педагогічних закономірностей, обумовлених дією фракторів [3, с. 80]. Своєю чергою Є. Хриков обстоював думку, що педагогічні умови - це обставини, які обумовлюють певний напрям розвитку педагогічного процесу [15, с. 3]. Водночас О. Пєхота розглядає педагогічні умови як обставини, за яких компоненти навчального процесу (зміст, викладання й учіння) подані в найкращому взаємозв'язку та створюють атмосореру плідної співпраці між учителем й учнями, що забезпечує плідне викладання, керівництво навчальним процесом, а учням успішне навчання [9].

Узагальнюючи вищезазначене, під педагогічними умовами професійного розвитку вчителів початкової школи в системі методичної роботи закладів загальної середньої освіти пропонуємо розуміти сукупність обставин, які забезпечують еорективність процесу профресійного розвитку вчителя початкової школи в системі методичної роботи закладів загальної середньої освіти.

Досліджуючи організацію методичної роботи 3 вихователями дошкільних навчальних закладів, О. Корнєєва стверджувала, що ефективність організації методичної роботи залежить від реалізації таких педагогічних умов: залучення вихователів до активної самостійної пошуково-методичної роботи; озброєння вихователів інноваційними методиками; занурення вихователів в інноваційно-творчу методичну діяльність; стимулювання оцінно-контрольної діяльності вихователів у профресійно-методичній роботі [6, с. 17].

Отже, на основі здійсненого аналітичного огляду психолого-педагогічної літератури й результатів констатувального етапу експерименту були визначені педагогічні умови, що сприяють професійному розвитку вчителів початкової школи в системі методичної роботи закладів загальної середньої освіти, а саме:

1) створення інноваційного професійного електронного середовища в системі методичної роботи;

2) оновлення змісту діяльності методичного об'єднання вчителів початкової школи, орієнтованого на вдосконалення професійного розвитку вчителів початкової школи;

3) залучення вчителів початкової школи до різних інноваційних фрорм методичної роботи;

4) системна взаємодія методичних установ (школи, району, об'єднаної територіальної громади);

5) відкритість і співпраця, що забезпечується залученням батьків (особами, які їх замінюють), 
представників громадських організацій, наукових і методичних установ, засобів масової інфрормації (далі - 3MI).

Вибір умов можна пояснити.

Перша умова: створення інноваційного профресійного електронного середовища в системі методичної роботи.

Тенденції розвитку освіти в Україні зумовили необхідність упровадження інноваційних процесів у системі методичної роботи закладів загальної середньої освіти, заміну традиційного профресійного середовища новим інноваційним із залученням цифрових технологій. Відповідно до сучасних вимог щодо організації методичної роботи з педагогічними працівниками в закладі освіти, методичному кабінеті району/міста (далі - РМК (ММК)), об'єднаної територіальної громади (далі - ОТГ), окрім традиційної документації необхідно передбачити наявність у друкованому та/або електронному фрорматах таких матеріалів, як-от:

- науково-методична література (виставка, картотека); аудіо-, відеотека найкращих освітянських доробків закладу освіти;

- авторські програми, методичні й навчальні посібники, розроблені педагогами закладу, професійне портфоліо;

- матеріали дослідно-експериментальної й інноваційної діяльності (накази, програми, реєстраційні й інорормаційні картки, договори про наукову співпрацю з закладами післядипломної педагогічної освіти, угоди про наукове керівництво інноваційною діяльністю);

- картотека педагогічного досвіду й освітніх технологій (матеріали передового педагогічного досвіду; банк даних про вчителів, які працюють в інноваційному режимі; картотека психолого-педагогічної літератури й перелік рекомендованих тем для написання методичних розробок учителями);

- віртуальна онлайн-спільнота професійного розвитку для взаємодії між учителями початкової школи інших закладів загальної середньої освіти та РМК (ММК).

В об'єктивних умовах інтенсивної цифровізації освіти та 3 метою підсилення методичної роботи учитель має можливість працювати над створенням власного педагогічного електронного освітнього ресурсу, яким може бути блог (сайт), електронний навчальний кабінет тощо, тобто електронне освітнє середовище (рис. 1).

Такий ресурс варто вести за окремими орієнтовними розділами, а саме:

- загальні відомості про вчителя;

- результати педагогічної діяльності;

- науково-методична діяльність: веббібліотека (матеріали, що містять обґрунтування вибору освітніх технологій, використання цифрових технологій в освітньому процесі; робота в методичному об'єднанні, участь у методичних і предметних тижнях; організація та проведення семінарів, вебінарів, круглих столів, майстер-класів; розроблення авторських програм тощо) та інші.

Друга умова: оновлення змісту діяльності методичного об'єднання учителів початкової школи, орієнтованого на вдосконалення професійного розвитку вчителів початкової школи.

Нами здійснено аналітичний огляд 25 планів методичного об'єднання (методичних осередків) учителів початкових класів з різних областей

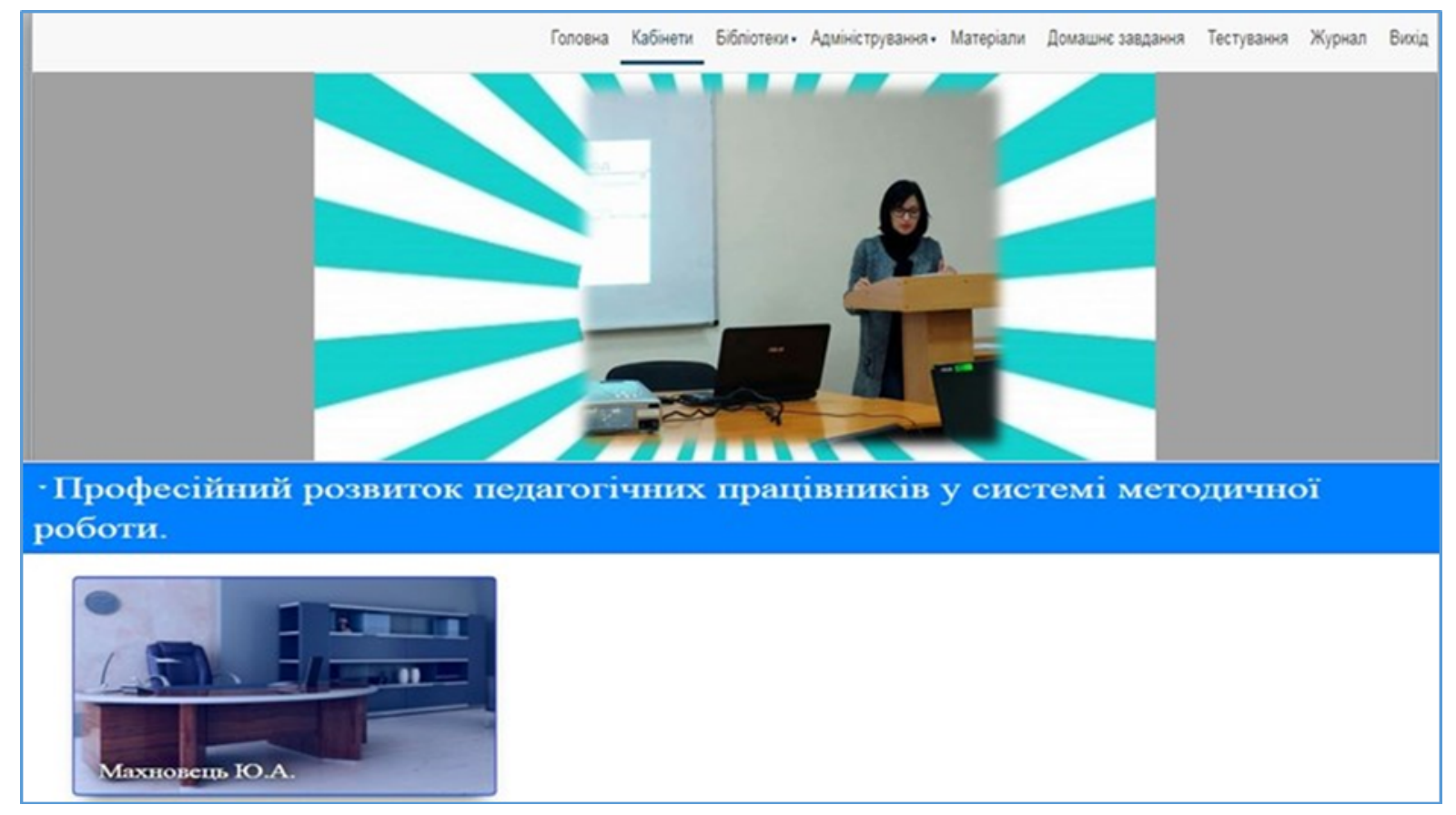

Рис. 1. Електронне освітнє середовище вчителя початкової школи 
України за останні два роки за такими критеріями: індивідуальний підхід до учнів (дитиноцентризм); інтерактивна участь учителів початкової школи в різних срормах методичної роботи; компетентнісний підхід до планування діяльності вчителя; педагогіка партнерства. Було виявлено недостатню позитивну результативність методичної роботи вчителів початкової школи, а саме: відсутність компетентнісного підходу до планування діяльності вчителя й індивідуального підходу до учнів (дитиноцентризм), майже не відображено інтерактивної участі вчителів у різних формах методичної роботи й реалізації педагогіки партнерства.

Варто зазначити, що методична робота вчителів початкової школи потребує поліпшення, але $є$ перспективною, оскільки стала більш відкритою на сайтах закладів загальної середньої освіти.

Під час оновлення змісту діяльності методичного об'єднання учителів початкової школи варто враховувати вимоги Концепції НУШ, пропозиції й конкретні методичні запити педагогів. План роботи має містити вступну частину, в якій необхідно дати аналіз результативності роботи закладу освіти, РМК (ММК), ОТГ щодо реалізації положень законодавчих і нормативних документів про освіту; проаналізувати роботу методичної служби 3 вивчення, узагальнення та впровадження в практичну діяльність інноваційних технологій, передового педагогічного досвіду, експериментальнодослідницької роботи за рік; окреслити проблеми, над якими буде працювати колектив, і визначити шляхи їх розв'язання.

Зміст планів роботи методичного об'єднання може доповнюватися відповідними змістовими додатками: діаграмами, графіками, скріншотами, схемами, наказами про структуру методичної роботи з педагогічними кадрами тощо.

у плануванні необхідно передбачити вивчення перспективного педагогічного досвіду, узгодженість методичних заходів з РМК (ММК), ОТГ. У цьому контексті варто розпочати роботу 3 підбору й опрацювання науково-методичної літератури з проблеми вивчення досвіду, а також розробити відповідні пам'ятки-рекомендації. Важливо надавати методичну допомогу 3 питань, які виникали під час вивчення досвіду. Матеріали досвіду повинні бути систематизовані й містити узагальнений опис, який вноситься до районного/міського/територіального й обласного банку передового педагогічного досвіду. В сучасних умовах оновлений зміст діяльності методичного об'єднання вчителів початкової школи доцільно розміщувати на сайті закладу загальної середньої освіти.

Третя умова професійного розвитку вчителів початкової школи в системі методичної роботи - залучення вчителів початкової школи до різних інноваційних фрорм методичної роботи.
Для того щоб методична робота сприяла профресійному розвитку вчителів початкової школи, їхній підготовці до інновацій, засвоєнню змісту нових програм і технологій, варто залучати їх до різних інноваційних фрорм методичної роботи. I тому під час вибору інноваційних форм методичної роботи необхідно враховувати освітні завдання закладу освіти, РМК (ММК), ОТГ, кількісний і якісний склад педагогічного колективу, матеріальні та морально-психологічні умови.

Четвертою умовою професійного розвитку вчителів початкової школи можна вважати системну взаємодію методичних установ (школи, району, міста, ОТГ).

Традиційна система методичної роботи, що фрункціонує в закладах освіти, РМК (ММК), ОТГ, охоплює індивідуальні, колективні й групові форми, що перебувають в органічній єдності та взаємодії. В сучасних умовах системна взаємодія методичних установ має орієнтуватися на інноваційний зміст і нові методики навчання, що включатимуть в себе: розроблення методичних веббібліотек і надання вчителям вільного доступу до них; можливість скласти індивідуальний навчальний план (створення вебресурсів, де вчитель зможе отримувати у вільному доступі консультацію та, за необхідності, пройти навчання у фрорматі вебінару); можливість навчатися вдома (створення й запровадження адаптивних е-платфрорм для такої фрорми навчання); оновлену систему контролю якості освіти (розроблення вебінструментарію 3 вільним доступом учителів для контролю й оцінювання успіхів учнів); оновлену систему мотивації для вчителів (проведення конкурсів, запровадження заохочувальних заходів, застосування матеріальних винагород, які залежать від рівня цифрових компетентностей, педагогічної діагностики просресійного розвитку вчителів початкової школи). Вибір конкретної методики залежить від практичної підготовки педагогів і їхнього досвіду, морально-психологічного клімату в школі, РМК (ММК), ОТГ.

П'ятою умовою професійного розвитку вчителів початкової школи в системі методичної роботи в закладах загальної середньої освіти є відкритість і співпраця, що забезпечуються залученням батьків (осіб, які їх замінюють), представників громадських організацій, наукових і методичних установ, 3МІ.

На засадах педагогіки партнерства пропонуємо створити методичну афішу як на рівні закладу освіти, так і на рівні РМК (ММК), ОТГ. Методичну афрішу розглядаємо як анонс науково-методичних заходів, які проводитимуться на шкільному, районному (міському), територіальному, обласному рівнях. До таких заходів можуть бути віднесені безкоштовні або за кошти учасників тренінги, квести, семінари, вебінари, конференції, екскурсії, коучинги тощо, які проходять як у робочі, так і у вихідні дні. Учитель відповідно до власного 
педагогічного інтересу зможе обрати види, фрорми, суб'єктів освітньої діяльності та сформувати індивідуальний навчальний план.

Висновки. Отже, передбачається, що фрормування окреслених педагогічних умов сприятиме ефективності технології професійного розвитку вчителів початкової школи в системі методичної роботи закладів загальної середньої освіти, що $є$ перспективою подальших розвідок у цьому напрямі.

\section{БІБЛІОГРАФІЧНИЙ СПИСОК:}

1. Kartashova L.A., Bakhmat N.V. Professional and pedagogical education of the primary school teachers: the European Union countries experience [Electronic resource]. Modern achievements of science and education XII International Conference [Israel, Netanya, September 17-24, 2017]. Netanya. P. 106-110. (last access: 12.03.2019).

2. Академічний тлумачний словник української мови [Електронний ресурc]. URL: http://sum.in.ua/ (дата звернення: 11.03.2019).

3. Бабанський Ю. Педагогіка : підручник. Москва : Знання, 1998. 386 с.

4. Великий тлумачний словник сучасної української мови. Київ ; Ірпінь : Перун, 2005. 1728 с.

5. Зязюн І. Філософрські засади освіти: освітні і виховні парадигми, освітні технології, діалектика педагогічної дії. Педагогічна майстерність у закладах профресійної освіти : монографрія / за ред. Н. Ничкало та ін. ; Інститут педагогіки та психології профр. освіти АПН України. Київ, 2003. С. 246.

6. Корнєєва О. Організація методичної роботи 3 вихователями в дошкільних навчальних закладах : дис. ... канд. пед. наук : Слов'янськ, 2012. URL: https://mydisser.com/en/catalog/view/238/245/9848. html (дата звернення: 11.03.2019).

7. Кузьмина Н. Фундаментальная акмеология как важнейший ресурс процесса повышения продуктив- ности образования. Проблеми освіти : збірник наукових праць. Вип. 84. Житомир ; Київ, 2015. С. 14-19.

8. Нова українська школа [Електронний ресурс]. URL: https://mon.gov.ua/ua/tag/nova-ukrainska-shkola (дата звернення: 02.02.2018).

9. Пєхота О., Прасол Н. Підготовка майбутнього вчителя до впровадження педагогічних технологій в умовах інтеграції у світовий освітній простір. Проблеми та перспективи фрормування національної гуманітарно-технічної еліти : збірник наукових праць / ред. Л. Товажнянський, О. Романовський. Харків : НТУ «ХПІ», 2015. Вип. 42 (46) : Ідеї академіка Івана Зязюна у працях його учнів і соратників : матер. міжнар. наук.-практ. конф. 14-15 травня 2015 p. C. $348-355$.

10. Пєхота О. Підготовка майбутнього вчителя до впровадження педагогічних технологій : навчальний. посібник. Київ : А.С.К., 2003. 240 с.

11. Підласий І. Практична педагогіка або три технології : інтерактивний підручник для педагогів ринкової системи освіти / І. Підласий. Київ : Слово, 2004. 616 c.

12. Профресійний розвиток керівників і педагогічних працівників загальноосвітніх навчальних закладів у післядипломній педагогічній освіті регіонального рівня (за матеріалами Луганського обласного інституту післядипломної педагогічної освіти) / Т. Сорочан та ін. Луганськ : СПД В.С. Рєзніков, 2013. 524 с.

13. Пуховська, Л. Теоретичні засади просресійного розвитку вчителів: рух до концептуальної карти. Порівняльна профессійна педагогіка. 2011. № 1. С. 97-106.

14. Сластенин В. и др. Педагогика : учебное пособие для студентов педагогических вузов / под ред. В. Сластенина. Москва: Академия, 2002. 576 с.

15. Хриков $€$. Управління навчальним закладом : навчальний посібник. Київ : Знання, 2006. 365 с.

16. Хуторской А. Практикум по дидактике и методикам обучения. Санкт-Петербург : Питер, 2004. 541 c. 